\title{
CONSIDERATIONS RELATING TO CERTAIN ASPECTS OF THE APPEAL IN THE CRIMINAL PROCEDURE
}

\author{
D. Barbu
}

\section{Denisa Barbu*}

Faculty of Law and Administrative Sciences, Department of Administrative Sciences Valahia University of Târgoviște, Târgoviște, Romania

*Correspondence Denisa Barbu, Valahia University of Târgoviște, Târgoviște, Romania E-mail: aijjs@univagora.ro

\section{ABSTRACT}

The appeal constitutes a judicial mechanism made available to consumers and to the Prosecutor that aims straight for errors committed by a Court of law in its approach of jurisdiction. The term judicial error must be understood in this context as defined in its broad, drawing together both errors of fact and errors of law. Therefore, the appeal is made for the one dissatisfied with the Court decision as a veritable juridical panacea.

The role of the right of appeal is not limited to conferring the possibility of requesting a new retrial of the case. They serve the interests of private individuals higher interests, being accused of public order needs. Thus, the existence of remedies is required by principles such as finding out the truth, the right to a fair trial and the reasons for the population's confidence in the judiciary or the respect due to justice.

The new code of criminal procedure ${ }^{l}$ has reformed the system of appeal may be exercised in criminal matters, giving them a generous space between regulators, art. 408 and 470. We meet thus, in penal matters, the following remedies: appeal, opposition, and cancellation, opposition in cassation, review and reopening of criminal trial resulting from the absence of the person convicted. Distinct from these, we encounter the complaint which may be made against preventive measures (judicial review and judicial control on security) prepared by the Prosecutor during criminal proceedings and which is addressed to judge rights and freedoms. Still exemplifying, we may meet and demand the cancellation or reduction of the fine, governed by art. 284 of NCPP, and the examples do not stop there. We must note that, in our opinion these latter examples may be considered legal remedies only in the usage of the term largo sensu ,remedy”. From the etymological point of view, the appeal originates in French, designating a claim appel, a calling application, a request etc. addressed to persons or institutions in order that the latter to settle claims by the appellant.

KEY WORDS: remedies, appeal, procedure remedy, judgment

\section{BRIEF DETAILS OF EXISTING REMEDIES IN CRIMINAL MATTERS}

Existential reasons and the functions of appeal differ in the ratio of specifics in each of them, but they may be regarded as having a common denominator, that of ensuring the right to a double degree of jurisdiction. The right to a double degree of jurisdiction in

\footnotetext{
* The work is developed during the project sustainability with the title "doctoral studies and postdoctoral Horizon 2020: national interest by promoting excellence, competitiveness and accountability in Romanian fundamental and applied scientific research, contract identification number POSDRU/159/1.5/S/140106. The project is co-financed by the European Social Fund through the Sectorial Operational Program of Human Resources Development 2007-2013. Invest in people!

${ }^{1}$ The law no. 135/2010, published in O.M. Part I, no. 486 of 15 July 2010, with amendments and completions, NCPP.
} 
criminal matters is provided for in art. 2 paragraph 1 of Protocol No. 7 additional to the European Convention on Human Rights ${ }^{2}$ stating the following: "any person declared guilty of a criminal offence by a tribunal shall have the right to require an examination of the Declaration of guilt or condemnation by a superior jurisdiction. The exercise of this right, including the reasons for which it may be exercised, shall be regulated by law".

In the light of the aforementioned, the remedies constitute a repair mean, a procedural remedy, capable of optional using, to carry out a thorough legal and settlement of the criminal cases ${ }^{3}$.

Appeals have more classifications, depending on various criteria. Given that the right of appeal in exegesis generally exceeds the present study objectives, we will focus on the most important classification of remedies.

A criterion for the differentiation of the appeal is that of the conditions required to be met for exercising an appeal. In relation to this criterion, the remedies involve a dichotomous separation: paths of ordinary and extraordinary remedies. Ordinary remedies are appeal and opposition and are characterized by the fact that the legislature does not advertise the fulfilment of conditions for the exercise thereof. Another feature of the ordinary appeal lay in the fact that they are targeting the non-definitive judgments of courts. Extraordinary remedies are cancellation in opposition, appeal in cassation, review and reopening criminal trial resulting from the absence of the person convicted. They claim compliance with certain requirements for their exercise, namely: first, targeting only definitive judgments that bear the imprint of the final place; secondly, the reasons for which the extraordinary remedies may be exercised are expressly and specifically provided by law.

Regulation of rights of appeal is of fundamental importance in a procedural system, particularly in criminal matters, given that criminal repression is most intrusive in rights and freedoms of the person. Moreover, the remedies contributes to ensuring greater effectivity of the right to defense, the opportunity given to the appellant, to the recurrent or the contester, as appropriate, to subject its cause to be heard and through the filter of reason and by another court. The judge's fallibility is much better known and accepted as a truism, and precisely this characteristic inextricably linked to human nature, it is desirable to be reformed by means of redress.

\section{THE APPEAL HISTORY AND IMPORTANCE}

From the etymological point of view, the appeal originates in French, designating a claim appel, a calling application, a request etc. addressed to persons or institutions in order that the latter to settle claims by the appellant.

In legal domain, the remedy of the appeal has been noted since before Christ, in procedural law. The one who first introduced the remedy of appeal was Publius Valerius Publicola, roman consul who was instrumental in the establishment of the republican regime in VI century B.C. Rome. Through a law it has conferred the right to the men convicted to appeal to people using an action that enjoys a suggestive nomenclature: provocatio ad populum. This action was a matter for the people's assembly, which could be admitting and totally abolishing the judgment of the Court, or to reject it and maintain integrity in the first judgment, middle, intermediate solutions were not supported ${ }^{4}$.

\footnotetext{
${ }^{2}$ Both ratified by Romania through Law No. 30/1994 concerning ratification of the Convention for the Protection of the Human Rights and Fundamental Freedoms and the Additional Protocols to this Convention, as published in O.M., no. 135 of 31 May 1994.

${ }^{3}$ See in this respect, I. Neagu, M. Damaschin, Tratat de procedură penală. Partea specială, Universul Juridic, București 2015, p. 273.

${ }^{4}$ For developments, see I. Neagu, M. Damaschin, Tratat de procedură penală. Partea specială, Universul Juridic, București 2015, p. 277.
} 
The settlement continuity was provided by Canon law, with some nuances specific to the ecclesiastical rules 5 .

Pavel Kiseleff was the one under the leadership of whom was included in the Romanian legal domain the appeal possibility to be exercised via the adoption of a regulation. The organic regulation was a quasi-constitutional organic law promulgated in 1831-1832 by the Imperial Russian authorities in Moldavia and Wallachia ${ }^{6}$. He consecrated it under art. 263 the right of the Attorney at law.

Further, the appeal has received relevant regulatory a good period of time. Thus, under the leadership of Prince Al. I. Cuza was adopted The Criminal Procedural Codices which have foreseen under art. 169: "Sentences given in police matter that can be attacked on the way of appeal when they will decide imprisonment, or fines, or repairs and restitutions and civilians will pass by their will, regarding money". And the Code of Criminal Procedure of Charles II foresaw the institution of appeal, granting it more articles (articles 15, 17, etc.). With the change of regime in 1947 was suppressed and the appeal of the appeal, this change would have the being proclaimed to ensure speed in the process. The appeal institution was absent from the legal horizon throughout the period of the Romanian Communist regime, totalitarian, being necessary a new change of regime in order to make possible the consecration of the appeal again. This was done in 1992-1993, when through the Law on judicial organization no. 92/1992 and the Law No. 45/1993 modifying and supplementing the Code of Criminal Procedure it was rendered the appeal in the palette of the remedy paths.

In the NCPP, the appeal enjoys generous rules in the context of Chapter III of Title III, was devoted to articles 408-425. The appeal is a way for ordinary remedies for reform.

The importance of the appeal in the current criminal procedure system economy is undeniable, and it was the appeal that allows the Prosecutor or the legislator to reclaim a new judgment in the substance of the case to another court or higher grade. The legal regulation of the appeal granted to the one dissatisfied with the judgment of the Court a second chance to be tried by an independent and impartial court. The importance of support and appeal is sustained by the constitutional provision of art. 129 stating about the possibility of the Public Ministry and the parties warranting an interest to pursue legal remedies.

Furthermore, art. 14. (5) of the International Covenant on Civil and Political Rights, as in force in Romania dated 20 November 1974, stipulates the following: "Any person declared guilty of a criminal offence has the right to obtain the superior jurisdiction, in accordance with the law, the Declaration of guilt and of his conviction".

In the Romanian procedural system, the appeal is the main tool that ensures the effectiveness of the right to a double degree of jurisdiction being a genuine appeal for reform which aims at shifting the mistakes where they exist.

The institution of appeal comes in support of recognizing the principle of truth, a platform principle of criminal law, in that the appeal is allowed a reassessment of the evidence and support participants in a process of argumentative, as well as the new administration and the formulation of conclusions written and oral.

Last but not least, the remedy of the appeal appears to the defendant sentenced in first instance as a genuine guarantee of the rights of the defense.

\section{THE PURPOSE OF THE APPEAL}

By understanding those judgments under appeal likely to be attacked on the way. Decisions are open to appeal provided for expressly by law under art. 408 para. (1): "Sentences can be appealed, if the law does not provide otherwise". To be able to delimit the scope of decisions open to challenge with is it is necessary the definition of sentence. This term has a different meaning from that accepted in current speaking, legal rigor impose a

\footnotetext{
${ }_{6}^{5}$ ibid., p. 277, quoted T. Pop, Drept procesual penal, Tipografia națională, Cluj, 1948, vol. IV, pp. 390-397.

${ }^{6}$ For details, see https://ro.wikipedia.org/wiki/Regulamentul_organic.
} 
clear delimitation between the names of the various decisions of the courts. Art. 370 para. (1) of the NCPP gives us a definition of the term sentence, stipulating the following: "the judgment by which the cause is resolved by the Court of first instance or by which it is not endowing without resolving the cause is called a sentence. The Court shall pronounce by sentence and in other cases provided by law."

At first corroborated reading of the law texts, it would seem that any judgment of first instance whereby the Court be dealt with either cause it not endowing, it would be attacked with the appeal. The assertion is only partly valid. It is true that, with his rule, the decisions to which we have referred above are appealed, but a series of exceptions come to confirm the rule. The exceptions to the rule consists in situations where, although the court decide a sentence, the legislature repealed the remedy of the appeal. In order to be in a situation where an exception is necessary a provision of the law removing the applicability of the appeal.

The second sentence of art. 370 para. (1) regulates another hypothesis in which the court shall decide by means of a custodial sentence, taking the opportunity of the existence of other cases strictly prescribed by law, distinct from the two mentioned above. In this sense, we witness the article 74 para. (1) para. 1, 459 para. (5), 469, para. (4) etc. However, in these cases the sentence is callable only in so far as the legislature has not acted otherwise. An example where the legislature provides otherwise is even in matters at the cause of dislocation incident when, although the court decides a sentence, in art. 74 para. (6) the final character proclaims these verdicts, not permitting the appeal against it.

Also, there are circumstances in which the sentences handed down by non-investing of courts are non-attackable on the path of the appeal. Such an example we find in the competence matter in art. 50 para. (4) of the NCPP providing that "the disclaimer of judgment is not subject to appeal."

Given that in criminal matters the power to judge at first instance belongs to all courts in the judicial system, means that the appeal may be directed against the death sentences handed down by a court, tribunal, Court of Appeal, the Court of Military Appeals, the Military Court, even against a sentence handed down by the High Court of Cassation and Justice in cases provided for by art. 40 para. (1) of NCPP.

Further, art. 408 para. (2) and (3) regulates the legal regime applicable to discharges which Court acted, stipulating that "decisions may be appealed only together with the sentence, except where, by law, may be subject to separate appeal" and that "the appeal against the sentence is made and counts the discharges". It follows from the preceding rule whereby decisions are subject to appeal by the run-up to only once with the case. We note that this rule behaves, with exception cases where the NCPP lay attacking with a separate appeal about a conclusion ${ }^{7}$. Another exception is the hypothesis opposition on the discharges with the separate track ${ }^{8}$. In the NCPP, as a rule, the decisions leading up to that are open on a separate path and are subject to contestation, and no appeal. Also, in the absence of any express indication in the statement of appeal, appeals sentence leads attack on ope legis and attack the discharges prior to the appeal.

Exemplifying, the legislature does not allow for the exercise of the appeal in the following situations: where the Court shall decline jurisdiction or acted a regulator of competence, with regard to resettlement, rehabilitation, in terms of enforcement of sentences,

\footnotetext{
${ }^{7}$ Art. 410 paragraph (2) stipulates the following: ,in the case referred to in article 409 para. (1) let. e), the appeal may be exercised immediately after the conclusion of the willing on the trial expenses, allowances and judicial fines and not later than within 10 days of the pronouncement of the sentence which has settled the case".

${ }^{8} \mathrm{See}$, in this respect, the decisions handed down by the first instance during the closing measures judgment, with the preventinve open opposition within 48 hours of ordering or communication, as appropriate - art. 206/NCPP.
} 
as well as in the event of invalidity by a Court of a final decision, or a decision open to appeal $^{9}$.

Summing up the above, in general rule, the sentences of the Court are appealed, and with the latter the decisions leading up to that were not the subject of this request or appeal on other way.

With regard to the jurisdiction to hear the remedy of the appeal, the NCPP innovates, assigning the jurisdiction to hear the appeal against death sentences handed down by judges and courts, and the Court of appeal against decisions of first instance courts of appellate jurisdiction to resolve the call returns the High Court of Cassation and justice. Also, against the judgments of the first instance of the I.C.C.J., the jurisdiction to hear the appeal is attributed to the bench 5. With the apart title, in the matter of the offences committed by the military power to resolve the appeal, it returns either to the Court of Military Appeals, or to I.C.C.J. as the cause was adjudicated at first instance by the Military Tribunal, the Military Court of Appeal, respectively. Competent panel to judge the appeal shall consist of 2, 3 or 5 judges, in the light of the court competent to judge the appeal ${ }^{10}$.

\section{PERSONS TO EXERCISE THE APPEAL}

The matter is given by art. 409 from $\mathrm{NCPP}^{11}$ which assigns the right to appeal a judgment of the first instance of a wide range of people, confirming once again the ordinary character of this appeal.

Previously, it should be noted that the interest, although the condition of the exercise of civil action, finds a fertile area and in exercise of his right of appeal. Therefore, in an effort to attack a decision represents a condition sine qua non for admissibility of appeal ${ }^{12}$. Where the legislator does not justify the interest of an appealed judgment, we appreciate that the sanction is inadmissibility incident.

From the text of article 409 of the NCPP it can be seen that the right to appeal a sentence is conferred by the legislator: to the parties at the criminal trial (the public prosecutor, the accused, the civil party responsible, the civil aggrieved person, the witness, the expert, the interpreter, the advocate) to third persons outside the criminal process (any natural or legal person whose rights or legitimate interests have been damaged by a measure or by an act of the Court) as well as the legal representatives and the trial substitutes (lawyer, legal representative, spouse of the defendant). The right to appeal the judgment is confined to certain people only to particular solutions of the proceedings, as we shall see below.

The Prosecutor, as the basis of the indictment, and in his capacity as representative of the interests of the State, is obliged to exercise the appeal under the criminal side of the case and the civil side of the case. If the criminal side of the Prosecutor's interest to pursue the appeal is undoubtedly, under the civil aspect there were controversies over the years.

\footnotetext{
${ }^{9}$ For examples of such a judgments not attackable with appeal, see M. Udroiu, Procedură penală. Partea specială. Sinteze și grile, C.H. Beck, București, 2014, p. 248.

${ }^{10}$ The Court of Appeal and the Court of Military Appeals judges in panels of 2, and the I.C.C.J. judges in panels of 3 or 5 as appropriate. For additional details, see the Law. 304/2004 on judicial organization and published in the O. M. No. 827 of 13 September 2005.

${ }^{11}$ Art. 409 from NCPP provides as follows: „(1) May appeal: a) the Prosecutor, referring to the criminal side and the civil side; b) the defendant, in terms of criminal and civil side; c) civil side as regards the criminal side and the civil side, and the party civil responsible, regarding the civil side, and concerning the criminal side, to the extent that the solution of this side of the solution in the civil side; d) the injured party, in relation to the criminal side; (e), the expert witness, interpreter and lawyer, in terms of judicial expenses, allowances and proper judicial fines applied; f) any legal or natural person, whose rights have been directly injured by a measure or by an act of the Court in respect of provisions that have caused such damage. (2) to persons covered by paragraph (1) let. b)-f), the appeal may be declared by the legal representative or by a lawyer, and for the accused by his/her spouse."

${ }^{12}$ In the same regard, see, I. Neagu, M. Damaschin, op. cit. p. 281, N. Volonciu (coordonator), Noul Cod de procedură penală comentat, Hamangiu, București, 2014, p. 1005.
} 
Thus, there were authors who argued that the civil side of the case sits under the sign of the availability of the parties, thus not indicating the right of the Prosecutor to intervene in the private affairs of the parties through an appeal to the civilian side of the criminal case. On the contrary, it has voted a Constitutional Court in its decision no. 190 from $26.02 .2008^{13}$ through which it held down by law as follows: "The prosecutor is not party to any opponent, but he is involved in the process in order to guarantee the observance of the law. (......). Although it is about the civil side in a criminal trial, it is undeniable that in this area there are general interests which must be defended, and in the judicial activity of the Constitution it established the role of the defender for the District Attorney."

Therefore, the interests of the Prosecutor to appeal the civil side of the case is so required by law, and supported the decision of the Constitutional Court as argumentative.

Regarding the defendant, in his capacity as the passive subject of the criminal action and the civil action, he is the main interested in calling the sentence. The defendant can appeal the sentence of the court irrespective of the solution which it comprises. For example, the defendant can appeal to a non-criminal process based on the existence of causes of nonpunishment, while ensuring that the appeal should obtain the path of his acquittal on the grounds that the act did not exist, his interest manifesting itself in this case in relation to the civil consequences of the solutions. The defendant exhibits full freedom in the choice of the solution which it decides to appeal. In spite of this freedom of choice, the defendant's right to appeal the sentence of a court is not absolute. Thus, the personal character and independent of the appeal shows that the defendant can appeal this judgment of the Court only in relation to his personal situation, the reasons thereof and may not refer to other people, or not participate in the criminal process, whose procedural position could not change its own procedural situations $^{14}$. Exceptionally, we appreciate that there might imagine circumstances in which the defendant to justify procedural interest in exercise of the appeal on other people than his own person. For the latter case, we consider the hypothesis of the instigator that critical judgment of the Court in its determination, requesting the lifting of her on the grounds that there is evidence that the act has been committed by the author. The instigator's interest in appealing the judgment on other people is fundamental in this one case, because to the extent that it would obtain the author's acquittal on the grounds of art. 16 para. (1) let. c) of NCPP, would disappear the foundation of the instigator's conviction, on the understanding that the Commission of an act by the author is the prerequisite of the commitment of criminal liability of the instigator.

With respect to the ability of the injured person to appeal, this one is limited by the procedural position of the participant, only in the context of the the criminal side of the case. Consequently, the person aggrieved may appeal against court only under the solution of its appearance, the quality of the criminal proceedings in declaring an appeal on the civil side of the case. Of course, in so far as the injured party was legally constituted as a civil party in criminal proceedings, it will be able to appeal the sentence and the civil proceedings, but not as an aggrieved person, but as a civil party in the criminal proceedings.

The civil side enjoying a plenitude of powers in connection with the exercise of the call, which may appeal the sentence of the Court under both its sides. Things have not always been so state, under the old criminal procedure code existing on the country's civilian side could critique this solution of the Court only under its appearance. By lege lata, the solution is the rational one, given that most of the times the solution with regard to the criminal side of the case is decisive in enabling the Court to settle the civil side of the criminal process.

The party civil responsible for accessing the opportunities is to pursue its appeal. Thus, art. 409 para. (1) (a). c) of NCPP provides that the party responsible will be able to

\footnotetext{
${ }^{13}$ Published in O. M. No. 213 of 20 March 2008.

${ }^{14}$ N. Volonciu (Coordinator), op. cit., p. 1006.
} 
declare the civil appeal "regarding the civil side, and concerning the criminal side, to the extent that the solution of this side of the solution in the civil side." We should note that the right person to civil side of the appeal of a court sentence is conditional upon a certain influence on the settlement of the criminal side of the case has exerted on the civilian side.

Further, the NCPP grants active quality in declaring the appeal and some other subjects, namely: the trial witness, the expert, the interpreter and the advocate. They justify the interest of appealing this judgment only in part, with regard to the solutions concerning and directly affects them. The text of the regulations restricts the possibility of appealing the sentence "appropriate judicial expenses, allowances and judicial fines applied". The logical solution is one, being related to the specificity of the role played by each of them in the criminal trial. Thus, the witness, the interpreter, the expert are legitimated in to recover the costs of transport, accommodation and subsistence expenses which has resulted on the process in their task, and to the extent that it would be unhappy with the Court solution to these issues, they can appeal in this context.

Regarding lawyers, the text from article 409 para. (1) let. f) is considering the situation of lawyer engaged in appeal on its own behalf and not on behalf of his client. Thus, counsel ex officio dissatisfied with court fees established for logs on who submitted it can appeal its solution in the Court of Appeal.

For the witness, interpreter, expert and attorney, the law enshrining their right to appeal and the Court decision by which they were fined.

With the exception of the Prosecutor, the appeal may be exercised for the benefit of the above mentioned persons and their legal representative or lawyer. Furthermore, the law recognizes the possibility that for the defendant the appeal should be declared also by the spouse. Considering that the law on criminal procedure law is corrupt, we appreciate that a family member may not declare a valid appeal to the defendant, being not acceptable for the extensive interpretation of the norm.

Art. 409 para. (1) let. f) forms the basis of the statement of the external appeal for the criminal trial. The legislature does not distinguish, so any natural or legal person injured through acts or measures taken by the Criminal Court will be able to turn its harmful solutions. As distinct from the General conditions governing the performance of the call, we appreciate that in this case it is necessary to respect the following conditions:

- acts or measures taken by the Criminal Court to aim at and people other than the trial participants;

- criminal acts or measures of the Court to produce direct injury to external criminal trial persons.

These third party apart from the criminal procedure, there are not subjects of conflict, neither to criminal nor civil law nor does come under the category of subjects to the trial, as they are individualized under the art. 33 and 34 from NCPP ${ }^{15}$. The injured persons are thus practically "collateral victims" of the criminal process. An example of this is the disposition of the Court of the measure of extended confiscation of property which is the property of persons other than those who participated in the judgment at first instance.

Last but not least, for those people who are external to the process, the appeal can be exercised by their legal representative or lawyer.

\footnotetext{
${ }^{15}$ In this regard, see M. Udroiu (coordinator), Codul de procedură penală. Comerntariu pe articole, C.H. Beck, București, 2015, p. 409.
} 